\title{
Correction: Methylphenidate enhances neural stem cell differentiation
}

\author{
Jasmin Bartl ${ }^{1 *}$, Takatoshi Mori ${ }^{2}$, Peter Riederer ${ }^{3}$, Hiroki Ozawa ${ }^{2}$ and Edna Grünblatt ${ }^{1,3,4}$
}

\section{Correction}

After the publication of this work [1], we noticed an error whereby the images of Figure 1 and Figure 2 are interchanged and therefore do not correspond to their legends. The image of Figure 1 belongs to Figure 2 and vice versa. The corrected figures are given below.
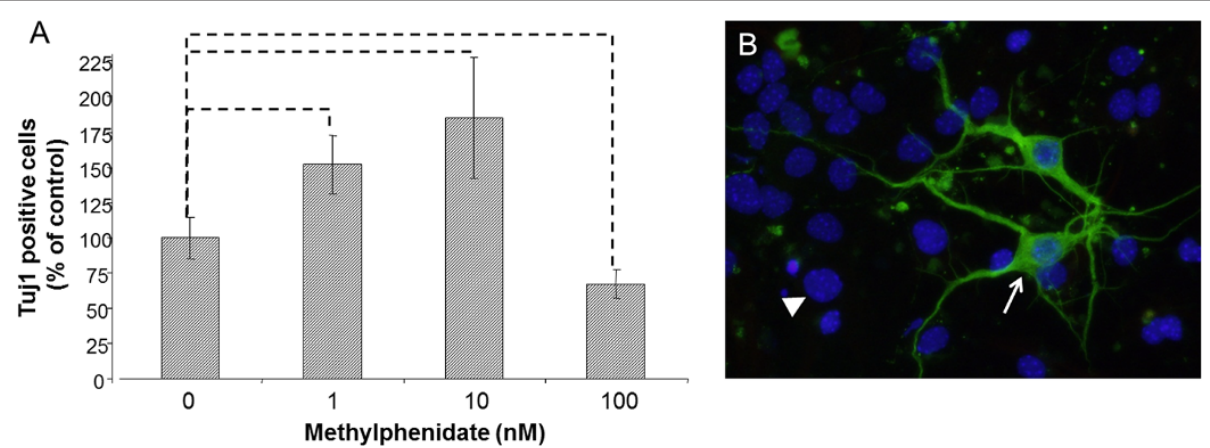

Figure 1 Murine neural stem cell (mNSC) differentiation into immature neurons. A) mNSCs were treated with different concentration (0nM, $1 \mathrm{nM}, 10 \mathrm{nM}, 100 \mathrm{nM})$ of methylphenidate (MPH). The percentage (\% control) of developed neurons was determined 4 days after treatment with $\mathrm{MPH}$. The amount of immature neurons was analyzed by counting the neuron-specific class III beta-tubulin (Tuj 1) positive cells in comparison to the total number of cells by using the Mann-Whitney (U-Rang) Test; -- $=p<0.05 ; n=28$; seven independent experiments and four wells/slide of each concentration were evaluated. B) An example of an immunocytochemistry staining of Tuj 1 in a control sample (no MPH treatment). The white arrow points to a Tuj 1 positive cell (green) and the white arrow points to a cell nucleus staining with Hoechst (blue); 40x magnification.

\footnotetext{
* Correspondence: jasmin.bartl@kjpdzh.ch

${ }^{1}$ Hospital of Child and Adolescent Psychiatry, University of Zurich,

Winterthurerstr. 180, Room L84/86, 8057, Zurich, Switzerland

Full list of author information is available at the end of the article
} 


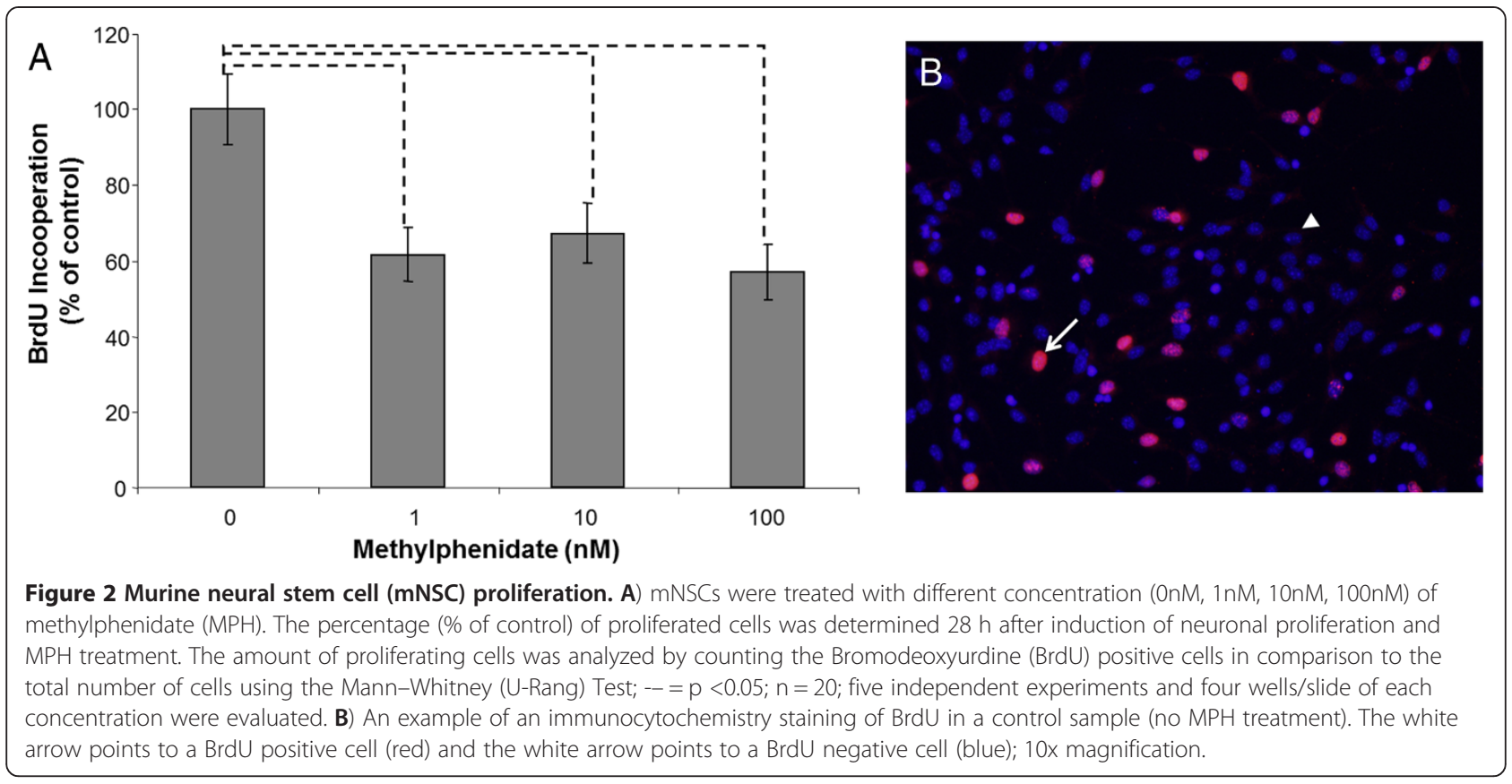

\section{Author details}

${ }^{1}$ Hospital of Child and Adolescent Psychiatry, University of Zurich, Winterthurerstr. 180, Room L84/86, 8057, Zurich, Switzerland. ${ }^{2}$ Division of Neuropsychiatry, Nagasaki University Graduate School of Biomedical Sciences, Nagasaki, Japan. ${ }^{3}$ Department of Psychiatry, Psychosomatics and Psychotherapy, University Hospital of Wuerzburg, Wuerzburg, Germany. ${ }^{4}$ Neuroscience Center Zurich, University of Zurich and ETH Zurich, Zurich, Switzerland

Received: 5 June 2013 Accepted: 5 June 2013

Published: 10 June 2013

\section{References}

1. Bartl J, et al: Methylphenidate enhances neural stem cell differentiation. J Mol Psychiatry 2013, 1:5.

doi:10.1186/2049-9256-1-10

Cite this article as: Bartl et al.: Correction: Methylphenidate enhances neural stem cell differentiation. Journal of Molecular Psychiatry 2013 1:10.

\section{Submit your next manuscript to BioMed Central and take full advantage of:}

- Convenient online submission

- Thorough peer review

- No space constraints or color figure charges

- Immediate publication on acceptance

- Inclusion in PubMed, CAS, Scopus and Google Scholar

- Research which is freely available for redistribution 